\title{
TWO CASES INFANTILE PERCEPTIVE DEAFNESS RELIEVED BY THE TREATMENT OF THE NASOPHARYNX
}

\author{
By \\ H. SHIBUI, M. SASAKI, M. IDEMITSU AND Y. YATOMI \\ From the Department of Oto-Rhino-Laryngology, School of Medicine Tokyo \\ Medical and Dental Unuverstty. (Director: Prof. S. Horiguchi)
}

Case 1. 6 years old girl. On the hearıng test, her both perceptive organs of inner ears was impaired, and hearing loss was about $60 \mathrm{db}$. After adenotomy, the patient's sujective symptoms, such as otalgia, tınnitus and deafness diappeared promptly. Her hearıng acuity was within the normal limits on the eighth day after the operation.

Case 2. 7 years old girl. Patıent's right ear was totally deaf and the left ear showed perceptive deafness with $35 \mathrm{db}$. hearing loss. $\mathrm{X}$ ray irradiation of Eustachian tube was done on the left side. After the treatment her hearng improved, and audiometrical test proved her left ear had the normal hearing.

Reviewing the literature, there are some reports that after tonsllectomy or sinus operation for the patients with the innerear deafness, their hearıng remarkably improved. These two cases are considered due to an allergic reaction in the labyrinth caused by focal infection.

\section{鼻咽腔治療による小児内耳性難聴の 2 治験例}

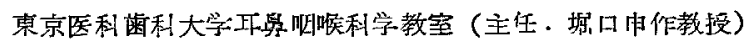

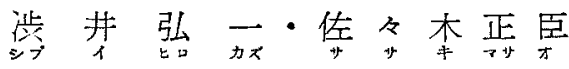

$$
\begin{aligned}
& \text { 出光誠・矢富良治 }
\end{aligned}
$$

\section{緒言}

近年，伝音器に関する研究は著しい進歩を遂げ，伝音 理論を背景にした聴力改善手術は既に矿究の段階を離れ て，日常臨床の問題とさえなりつつある. 然し，他方内 耳や聴神経関しては未だ不明の点が多く，今後の研究 に侯つ所大である・従つて，内耳性難聴に兴む多数の患 者は，多大の社会的ハンデイキャッブを負うた債，医療 から見放されていると云つてる過言ではない有様てあ 乃

これ等内耳性難聴に閣しては，その原因が不明のむの 多く，従つてその治療法に関てしは必ずしも，一定の見 解があると云う状態とは云い難い，最近我が教室ては， 鼻咽腔，耳管乃至中耳のカタル性炎症等の極めて軽度な 炎定性変化に併存し，これと消長を共にすると考光られ る骨導聴力変化を多く観察し, 所謂内耳性難聴と称せら れる骨導聴力の低下が，しばしばこれ等鼻咽膑万至耳管
の沿療に反応することを記载した。この論文も同様のこ とを証明するるのである 即ち今回，者等は，小児内耳 性難聴のアデノトミーによる治験例及ひ同樣患者の上咽 頭放身線照身憭注による治験例を経験したのて，ここに 発表する次第てある

症 例 (1)

患者· 宇○芳○ 6 才 女子

初䛦：昭和 33 年 11 月 29 日

主訴：難聴及び左耳痛

診断・両側内耳性難聴及び左急性耳痛性耳管炎

現病歴：本年 9 月始め頃，綝り返えし名前を呼ばな いと返事をしないのて，耼遠いのてはないかと云う事 に母親が気付いたその後，時々左側耳痛と耳鳴を訴之 る様になつた・聑唧はガーガー，そのため左の耳が聞え ないと訴えていたそうてあるが家庭の都合て放置してい た 11 月 28 日には学校て先生が数回名前を呼んても返 
事をしないのて，あなたは笽てすかと怒鳴つたと云う事 であるが，その日，直ちに学校の先生から家庭の方連 絡有り，耳番利医て精密検查を受ける事を推められて翌 日当和を受唁した訳てある・办これ迄，頭痛，眩最，耳 閉塞感挀兑た事は無いと云ら

既往歴 4 才の時, 祖母に難聴かあるのてはないか と云われた事がある・同様本年始めに英語を習つていた 叔母から、耳が遠いのてはないかと云われたそらてある が，3 月の小学校入学試驗の時には難聴の様子は全く認 められなからたと云う。

亦，本年 5 月，百日喛に䍜患し，本学小児科において スリマ14 本の住射を受けた事がある

家放歴 而親, 妋共に健在

初䧐時所見. (右鼓膜) 正常, (左鼓膜) 中等度の内 陷あり，楄胃柄上部にビンク色の軽い充血が認められ るこの充血は鼓膜自身の充血てはなく，鼓膜を透して 認められる鼓安岬の充血てあつて堀口教授の云う耳管炎

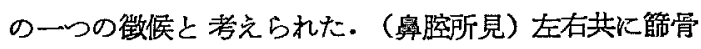
胞がや>膨隆してをり，中鼻介，下鼻介共に軽度の浮腫 性腫脹を呈し，総鼻道には秥液性鼻什小量眝溜してい た（後鼻鏡所見）咽頭反射が強く，や小肥大した咽頭 扁桃を認めた他詳細は不明てあつた（咽頭所見）異常 無し.

側頭骨・レ線写真所見 両側共に乳様蜂单の 発育良好 て異常所見は全く認められない。

初診時聴力像 因1のA の如く高音漸傾型の内耳

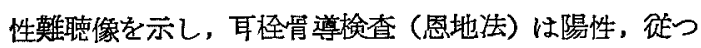
て伝音障害は否定される訳である 左側の鼓膜に内陮と 軽度の充血が認められるが, 伝音器に炎症性変化があつ たとしても音響伝導には殆んど支障をきたさない程度の 極めて軽微なものと考えざるを得ない。

治療経過 左側の鼓膜所見亡耳痛の訴えを考兄て一 応クロマ1 $1 \mathrm{gr} 2$ 日間内服せしめたが，全く軽块の 徵が認められなからた 2 日後, 德力像を確かめるため に再度聴力桧查を行つたこの時は困1のBの如く前 回より更に高度の内耳性雚聴像が得られ，特に耳痛, 耳 鳴，鼓膜発赤等の耳管炎の存在が考えられる左耳の聴力 が右耳より悪化してをり，算尊闇值は全周波数に和いて scale out そなつているのが見られる・その後, 患者は クロマイの内服を拒否するので，聴刀は秉も角として， 耳痛性耳管炎（堀口）の症状, 鼻カタ几の存在に呅しア デノトミーが有胶てあるうと考克，12月 5 日に手術を行 つた。
術後の経過は極めて良好で，2 日目頃から左側鼓膜の 発赤が消裉し，耳痛も軽減してきた５日目には左側鼓 膜は内陷を残すだけで発赤は全く消失し，亦耳痛，耳鳴 もすつかり治つて聞えむ良くなつたと云う8 日目には 学校の先生す普通聞えるらしいと云うので聴力検查を

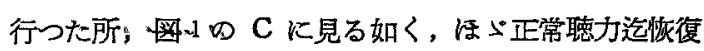
しているのに鳘かされた訳である.その後る経過の観察 を続けたが，術後 34 日目には左側鼓膜は内宿子消失し て全く正常鼓膜像を呈し，聴力子亦完全に正常に復して をり，(図 1，D）以後今日迄再悪化の 徽候は見られな w.
症 例 (2)

患者. ○内○子 7 才 女子

初誩. 昭和 33 年 12 月 6 日

主訴。右難崄

現病歴 昨年幼稚園に通つている頃は異常が 無から たようだが，小学校へ通学するようになつてから，学校 の教師に難德を指適され，教等では最前列に座らせるよ らにしていると云う・最近はラデオの音を非常に大きく しても良く聞き取れない。これ迄耳痛, 耳鳴, 眩暈の訴 えは無かつたとの事である

既往歴 乳幼時に中耳炎に䍜患した事があると云う が左右何れかは不明 亦, 本年 8 月には流行性耳下腺炎 に䍜患している。

家族歴．特范すべき事は無い。

初診時所見 (右㨬膜) 正常, (左鼓膜) や小内陥儿 ていると思われる他全く 異常所見は認められない（鼻 腔所見）中舅介が両側軽度に浮腫性腫脹を呈し，粉鼻道 に枮液性鲁什が貯溜してをり，上咽頭にはや小大きい咽 頭扁桃が認められた。

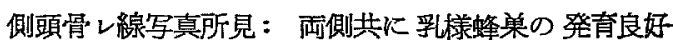
てあり，異常所見を認めない。

聴力像：図 2 の A に示扣く，右耳は全垶，左耳 が高音桷傾型の内耳性難聴てある。

治潦：12月10日より放射線科传頼して左側耳管 の潹部昭射を行つた 昭射方丢は1回 $100 \gamma$. 週 2 回で 全6回の昭射を行つた家人によれば放射楾治療を行つ ている間に，既に聴力が恢復してきたそうである・昭和 34 年 1 月 20 日に行つた聴力㭘查の結果は図 2,B の如 く左耳正常に復しているが，右耳は矢張り全監であつ た。

考按

一般にアデノイドによる難聴は，閉塞性耳管炎を直接 
图 1

A

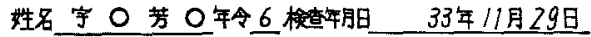
住所

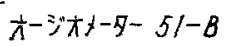

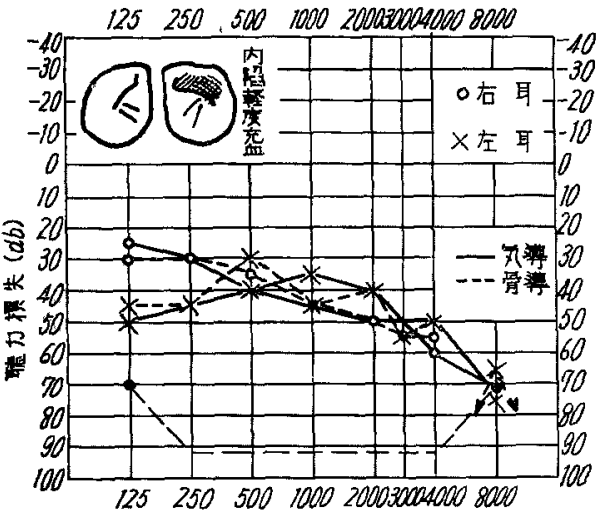

C

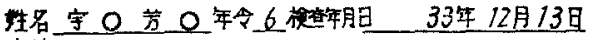
住所

$$
\text { オージオイーター }
$$

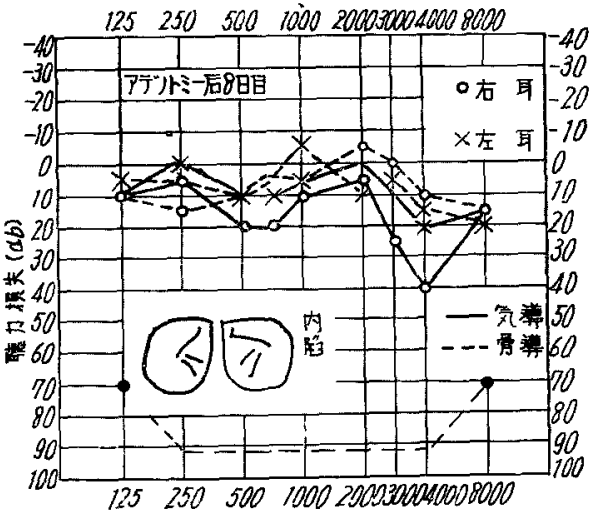

図

A

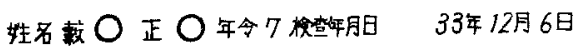
住所

オーデイン゙ータ- $51-B$

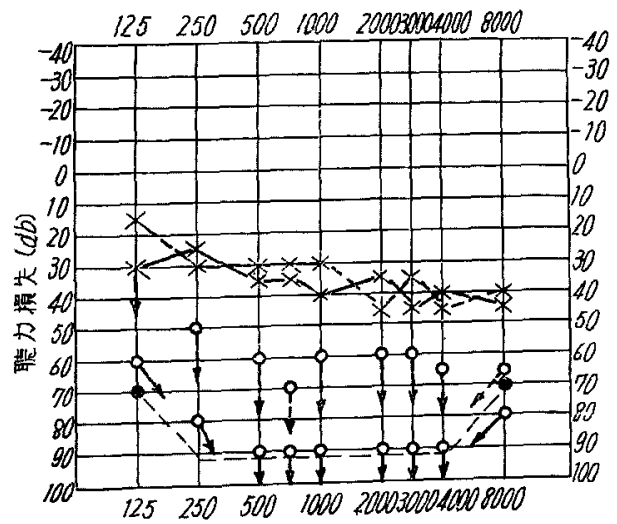

B

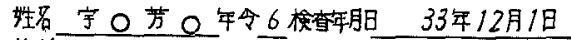
住所

$$
\text { ホーン゙オーター } 51-8
$$

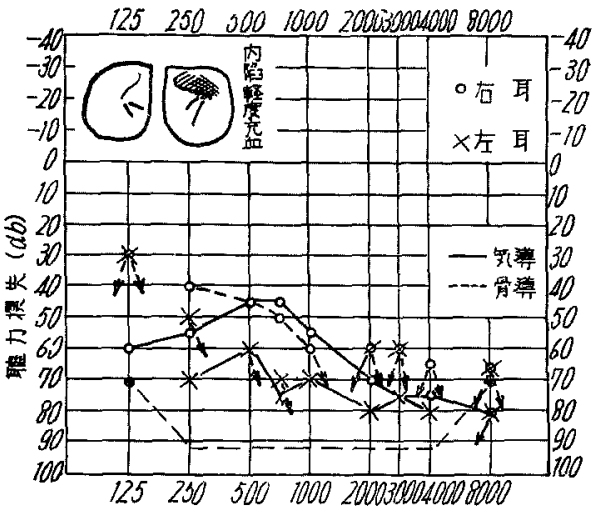

D

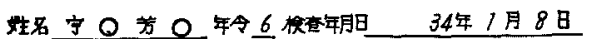
住方

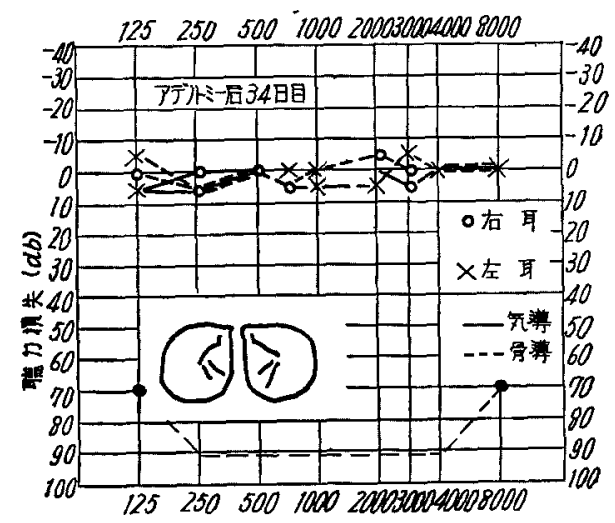

2

B

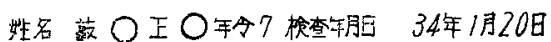
往所

(2) オーシオケ-8- 51-B

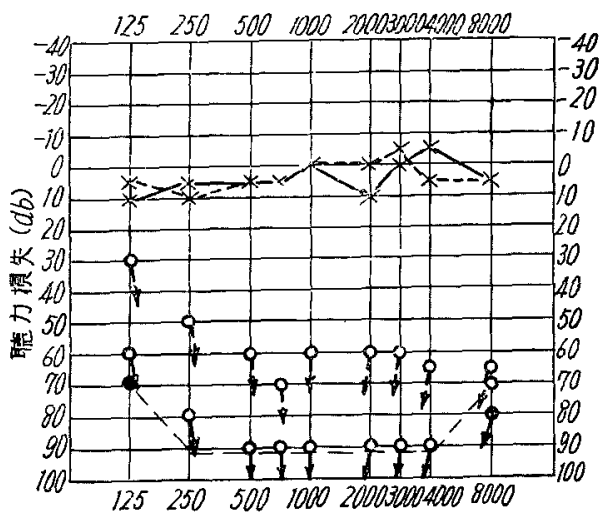


A

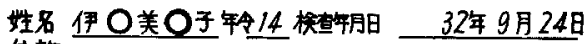
住施

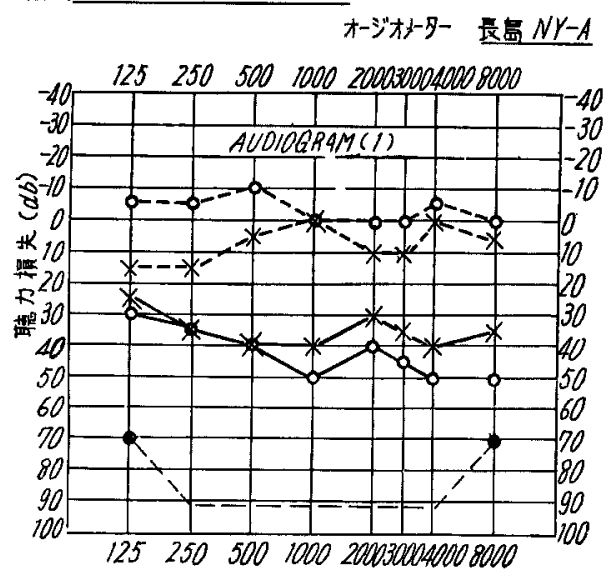

原因とするものてあつて，骨尊䦭值は正常にとどまり， 気導聴力のみ障害される典型的な伝音柔難德てあると考 六られる.1例を示すと，四了の A の如くてある この例は 1 度通気を行うと $\mathrm{B}$ の如く著明な渎力改善が 見られ，気導闒值は正常に近附くか，な和気，冝導間值

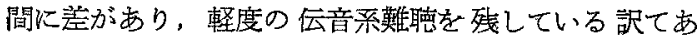
る.この事は德力障害の大部分か中耳の Veut1lation の障害に基くものてあつて, 通気後にも残存する気, 肙 導闎值差が伝音器の炎症性変化及び中耳腔陰圧に伴う二 次的な粘膜の充血，浮婳あるいは補腔水腫等による伝音 障害を示すむのてあるこの例の患者は15 才の女子て， 通気を行うと 3 日間位聞え心良いが再び惠化し，通気療 法を綕けても全治は難かしく思われたのてアデノ、ミー を行って概ね生治せしめた症例てある・しかし乍ら，前 に挙げた報告例は，このような聴力像とは著しく異って

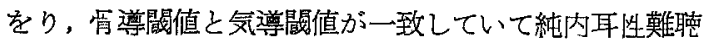
像を呈している 患者が小児てあるため Recrintment の検查は不可能てあつたか，種々の点から気導並びに 肯導 Audiogram には充分の信頼を置くことがてき る。

内耳障害をきたす原因は数多くあるが，その中には中

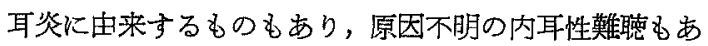
る.堀口，角田は䝢性中耳炎の骨導聴力を調べて，㱏導 聴力損失の認められる患者の割合が罹患後年数之開俰無 く大体一定てあつた事実から，内耳障害の起るのは，中
B

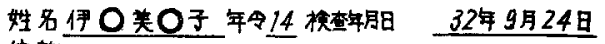
住所

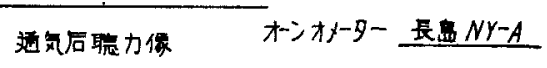

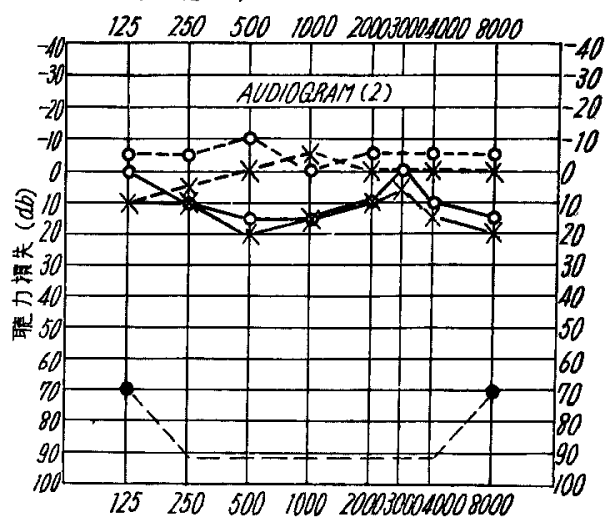

耳矣患の極めて初期であうらと推諭した・亦堀口，鰕原 は耳管炎の聴力像を検訫した結果，倱合性難聴像を示す ものが中耳炎の埸合より更に多く見られたと報告し，更 に，原因不明の内耳性障害の中，耳管炎(この耳管炎を 特に閉塞性耳管炎即ち耳管狭窄症に限定して見た場合に 赫いてさえも）を合併するもの多く，及耳管炎患者の Audiogram を連続的に観察して行くと，内耳性障害の Audiogram に到達することか愿るあると云う事先を報 告している.

一般に骨導オーヂオグラムの低下が気導のそれと相等 しいものを感音障害あるいは神経性難聴と称している が、これが必ずしも内耳感音器の障害そのるのを表わし ているかどらかといら事に関しては証明がない.Carha rt 以後，县導聴力は必ずしも内耳機能を表わするので はないと考えられるようになり，Palva \& Ojala の如 きは，中耳炎症例㹸見られる脣尊㯖力の低下゙の原因を， 両内耳空の可動性制限に求めんとしているぶ，彼等の根 拠としている DL test の結果は，そ㣗程信頼を置き得 るむのてはない. 亦, Hulka Erıc Carlens は, 急 陦中耳炎に見られる高音部骨導聴力損失を，中耳病变に よる過牛基礎回転の请の結果としているこのよう に，中耳病変に基因すると考えられる内耳変化の文献に 対し，一方急性癸登性難聴関する交献はかなり多く見 られるか，この疾患の原因閏する諸家の考えは必ずし も一様ではない，勿論この疾患は同一疾患のように見克 
ても，その病因は必ずしも同じものとは限らず，恐らく Hallberg の云う如く，一つの症候なのてあらう．何故 なら，交献上飞見られる治験例の尾々相，それに伴ら病 因関する見解の相異，あるい恃同一治療法による治療 効果が症例によつて著しく異つている事等が，急性宛発 性奞聴の凡てを同一病因によると考えては到底理解てき ない事であるからに他ならない

例光ば, van Dishoeck \& Bierman は100 例の sudden deafness の中， 40 例何等汃の virus 感染の症 状を認めてをり，福田は中耳炎を伴わない、流感つん ぼを記載して，耳下腺炎と同じょうに内耳あるいは聴 神経をV1rus が侵すためであるうと述べている

亦, Kobrak $か ゙$ Angioneurotische Oktavkrise $と$ 呼んで以来. 内耳の出血, 血栓, 血管座杽等の血行障害 を考える者多く，更に Hilger, Mygind の如く内リン バ圧上舁に病因を求めんとするすのが現れ，Ménière 氏病の一異型としてEndolymphatic hydraps without vertıgo なる概念を提唱する者るある (Will

その他代第 8 神経の Neurit1s と考元るもの (SvaneKnudsen 及び Bocca \& Giordano), Atherosclerosis との関係を重要視するものもある 亦血行障害の原因 として棈神的衝撃, 自律神経障害を考えるるのるある (Fowler, 堀口). 亦内耳出血の原因として網膜出血の 場合と同樣アレルテーを教觉可きてあるとする者す出 てきた・岩田はレイリー現象とストレス学説を取り上

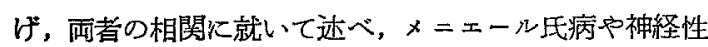
難聴の発現機転にこの両寻説を導入す可き事を説いてい る.

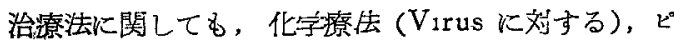
ロカルピン，ノポカイン点滴静注，二コチン酸，重曹 水,ビタミン $\mathrm{A}, \mathrm{B}_{1}, \mathrm{~B}, ル$ ルン，コンドロイチン硫酸， 頸部交感機経遮溯，コーチゾンその他のアレルキ一療 法, 減夜神法, 低食塩療传, 内耳開究術等か挙けられる が，中には自然に治撚するるのもあるらしい. Heller \& Lindenberg は Sudden deafness の5例の中 7 力 月後に自然に治嘹していた1例を迹へ，森山他は同様目 然治瘉した2例を記䡛している・亦，耳管通気佉を行 つた所，直らに著明な好転を示した症例の報告も見られ る(Kalmon et al) 乙かし, これ等の治㞠生や，原因 等から推察するとき，少くともその一部には悬咽胵乃至 耳管の尒症性変化に伴ら内耳のアレルキ一性変化を考学 ることの妾当性を有するものが含をれていることは考え られる。
著者等の経験した症例（1）は，アデノトミーによつ て沿湑したものと考允られ，症例 (2) は左耳のみである が耳管のレ線照射で治瘉している 耳管の $\mathrm{X}$ 線照射に 上る内耳性難聴の治療に関しては，河田教授の考える如

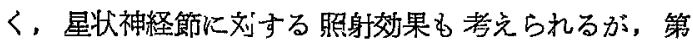
(1) 例かアデノトミーにより治痖している事実から考皇 れば，これとの類似性を考劣て，X線効果が耳管扔至鼻 咽腔に及几たと考光る事も妥当てあると思う・少くとる 堀口教授はこのような考えである。

文献を見るに，上気道の手術的操作によって内耳性難

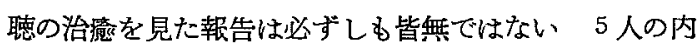
耳性難聴患者に扇桃腺摘出を行つて，著朋な聴力改善を 諗めたと云う Maleck1 の報告，文び内耳性難猡患者の 上頡洞 Cyote の手術を行つた結果, 聴力改善を見た之 云う Linke の報告かるる. 亦, Atkinson が Ménière 上病のビタミン療去に就いて記した症例中，缽霖の摘出 後全く発作の止つた例の如きも私の報告例に近いと考觉 る事がてきるのてはなかららか，前述の Maleck1や Linke 恃共红 focal infection に上る内耶障害を考光 ているようてある

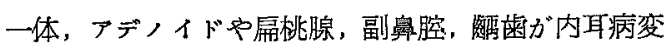
とどのような関聯性を有するむのてあろらか. 勿論これ 等の器官と中耳の炎症一内耳病变を考える事は容易てあ るが，少くとも肉眼的には中耳炎定が認められないよう な軽度な炎症てもこの傷言経路引成り立つものてあろら か この点に関しては, Elic Carlens は Loudness balance test を行つて Mucosus 菌少内耳障害を起し 易いと述べている・従つて，このような菌の focus と してアデイト，扁恌腺，副鼻腔炎を考光る可きてある らか. 更に亦, これ等鼻, 咽, 口腔内病香の産生物, 若 しくはそれと関聯せる耳管，中耳の極めて軽微な炎症と 内耳との問にアレルキーの成立を考觉る可きてあるら か、私の経験した僅か 2 定例から，これ等重要課題に就 いて論する事は不可能てある今後臨床例が重ねられ， 実験的矿、究が行われるよらになれば次第に明らかになる てあうう。

但し，敢えて可能性を論ずるなら，focal infection に伴らアレルキーを考学るのが最も考党易い上らに思 5. 何故なら, 内因性喘息の原因として病单紫染から発 生する毒素によるアレルキール外られてをり，この晨合 虫垂炎，胆賈炎，肯盤内疾患の手術あるいは扇桃剔出，

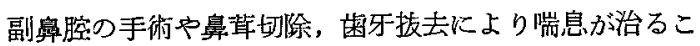
とがある・亦, 内因泩喘息の半数例に副鼾腔矣患が見ら 
れると云ら事実を考えるならば，気管支と内耳を置き換 党てみるだけで, 本報告例, Maleck1, Linke, Atkinson の例が喘自の埸合と極めて頻似しているのを゙何人す疑い 得ないであろら．堀口，鰕原が鼻咽腔に炎症の認められ る sudden deaf の症例には Cortisone 療法が極めて卓 効ありと報告しているのを考え合わせるなら，一層上速 のアレルギー説を良く首肯する事わ活でる.亦 Kalmon et al の症例中, $121 / 2$ 才の少年の如くアデノィドの 見られる感音系難㯖に抗ヒスタミン斉べナの投与を行つ たのみで治澺している争実る亦アレルギーを考光ささる ものである. 勿論高音急榇型の甚だしい例は何等かの血 行障害を考えざる得ないるのであつて内耳性難聴の凡 てをアレルキーなりと考光る訳でない事は云う迄もな W.

鬼もあれ、アデノトミ一の起義に㢹いて，堀口教授が

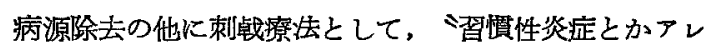
ルギー等に対して，必ずしも当险扁桃自身に限らず，乙 ばしば別の器官に対しても有效に作用するという積極的 な意味を有つるのと信じている、と述べているのは誠に 卓見といらできてあると思う・

慢性中耳炎に対して，アデノトミ一が卓効ある事は， 高橋が記載している如くてあるが，慢性中耳炎や耳管炎 のみならず，本報告例の如き高度の内耳性難聴の小呪に 対してす，従来つ如く征らにビタミン注射のみに頼る事 無く，今後は一応アデノトミ一あるいは上㸶頭レ線照射 設試みる可きてあると考党る。

\section{結語}

6 才女呪の膏度の内耳性難聴症例にアデノトミーを行 つた所，急激に症状が好転，聴力が全く正常に恢復した 1 例，及ぴ 7 才女坚，1 側全舞，他側内耳性難渎の症例 に上胭頭線照射を行つて内耳性䧳聴側のみ治瘉したI例 を報告したこのような症例の内耳性難聴の成因，治療 機転共に不明てあるが，遇然上記の治療法によつて治丞 せしめ得る状態にあつたすのてあろう・しかし、䅜なな 点から考えて，病㫦感染による内耳アレルギーを考える のふ最も穏当であるよらに思われる・亦,このよらな事 実が存在したと云う事怡，広くは感音系知德，亦所謂原 因不明の突発性難聴の本態を究明する上に，極めて重要 な手掛りを与えるるのてあり，更にこれ等難聴の治療手 段にも何等かの暗示を与え得るものではあるまいか.

\section{主 要 文 献}

1) Hallberg, O.E.: Laryngoscope $66 ; 10,1956$.

2) Fowler, E.P.: Annals of Oto. Rhı. \& Laryng. 59; 980, 1950, 3) Svane-Kmudsin, V.: Acta-OtcLaryng. 47; 3, 270, 1957. 4) Van Dishoeck ant Bierman The $A$ : Annals of Oto. Rh1. \& Laryng. $66 ; 963,1957$. 5) Heller, $M F$. and Lindenberg, P.: Annals of Oto. Rh. \& Laryng. 46; 931, 1955. 6) Ka'mon, $M$, Miller, M.H. and Fowler, E.P.. Annsls of Oto. Rh1. \& Laryng. 66; 981, 1957.

7) Hilger, J.A.: Annals of Oto. Rh. \& Laryng. 59; 1102, 1950. 8) Maleckn, $J:$ Zentralblatt fur H-N v OHK. 56; 222, 1956-7. 9) Linke, HJ: Zentralblatt fur H-N-v. OHK. 54 ; 1955-6. 10) 堀口，角田：日耳罨，56；1953，11）切替, 武藤, 河称, 大島：日耳畺，56；1953 12）切替，北山： 日耳學，56；1953. 13）堀口信夫：日耳學，56;

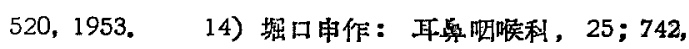

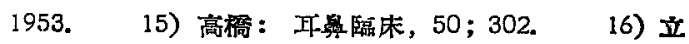

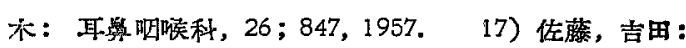

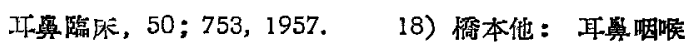
科, 29，1002，1957。19）福田：日采医新, No. $1735 ； 103,1957.20$ )岩田：日本医新, No. 1735;

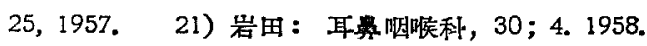
22) 岩田：耳警咽崌利，30；8, 1958. 23) 堀口, 解原：日留，61；Suppl. 1958.24）堀口, 鰕原： Andiology 1；No. 1, 1958. 25) 松本：直算隐 㸝，52；19，1959.26）森山他：日耳無，62；1959. 27）堀口, 鰕原：日耳基，62，6，1959.28）Polva， $T$ and Ojala, L.* Acta Otolaryng. 45; 137, 1955. 29) $H u^{\prime} k a, H . J \quad$ Archives of Otolaryng. 33; 1941. 30) Carlens, E.: Acta Otolaryng. 32 ; 1944. 31) Atkinson, M.: Archives of Otolaryng. 51; 149, 1950. 32) 传企- 内利学, 蛙.

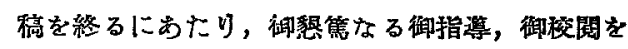
賜つた恩所堀口教授に対し深甚な謝意を䘚する次第 でらる。

本樀の装旨々日耳學関東地方会第358回例回に゙ま いて発諘した。

（原穆到嚄 $=$ 昭和 34 年 2 月 26 日一急載） 